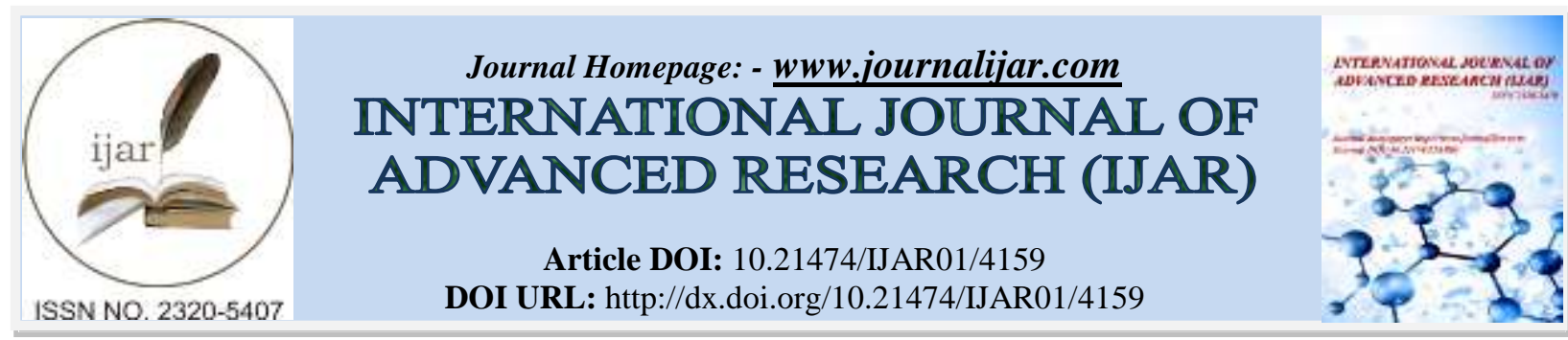

RESEARCH ARTICLE

\title{
EFFECT OF DIFFERENT LEVELS OF SALINITY ON BIOCHEMICAL PARAMETERS OF TRITICUM AESTIVUM L. VAR. RAJ-3765.
}

\author{
*Kiran mala and T.I. Khan. \\ Indira Gandhi Centre for Human Ecology, Environmental and Population Studies, University of Rajasthan, Jaipur- \\ 302004, India.
}

\section{Manuscript Info}

Manuscript History

Received: 15 March 2017

Final Accepted: 10 April 2017

Published: May 2017

Key words:-

Adverse effect, Biochemical parameters, Salinity levels, Stress and Triticum aestivum $L$.

\begin{abstract}
Salinity stress is a severe environmental factor limiting crop yield worldwide. Plants are sessile and frequently encounter variety of environmental stresses resulting in altered growth and metabolism. This study was conducted to investigate the effect of salinity on biochemical parameters i.e. carbohydrate, nitrogen, protein and phosphorus contents of Triticum aestivum L. var. Raj-3765. The experiment was laid out as a completely randomized design in a factorial arrangement with three replications. In order to determine the effect of salinity, Triticum aestivum $L$. var. Raj-3765 was exposed to different concentration of saline water and a control level (double distilled water) and its effects were observed. Salinity levels were prepared by adding different concentrations of Saline water (SW) and double distilled water (DW). It was found that carbohydrate, nitrogen, protein and phosphorus contents stimulated at lower concentration of salinity but reduced at higher concentration.

With decrease in salinity an increase in carbohydrate content was observed. At salinity level 6 (DW: SW:: 00:100) carbohydrate content was $35.54 \mathrm{mg} / \mathrm{gm}$ and at level 1 (DW:SW:: 100:00) control level, carbohydrate content was $40.32 \mathrm{mg} / \mathrm{gm}$ in pre-flowering stage. Similar results were observed in other parameters.
\end{abstract}

Copy Right, IJAR, 2017,. All rights reserved.

\section{Introduction:-}

Salinity is one of the most important abiotic stresses which is widely distributed in both irrigated and non-irrigated areas of the world (Ashraf et al, 2008; Kamal Uddin et al, 2009). Low temperature, drought and high salinity are common stress conditions that adversely affect plant growth and crop production. Salinity is one of the major factors reducing plant growth and productivity worldwide and affects about $7 \%$ of the world's total land area (Flowers et al., 1997). Soil salinity presents an increasing threat to plant agriculture as more and more of the world's arable land becomes salinized. Environmental stresses including salinity and temperature affect nearly every aspect of the physiology and biochemistry of plants and significantly diminish the yield. Plants are subjected to various stresses and they respond to them in the form of various biochemical changes in them which may be or may not be beneficial to them. The ability of plants to cope with salinity stress is an important determinant of crop distribution and productivity in many areas, so it is important to understand the mechanisms that confer tolerance to saline environment (Munns et al., 2006). Salinity is a problem for agriculture because only few crop species and genotypes

Corresponding Author:- Kiran mala.

Address:- Indira Gandhi Centre for Human Ecology, Environmental and Population Studies, University of Rajasthan, Jaipur-302004, India. 
are adapted to saline conditions. The term salinity includes all the problems due to salts present in the soil and interfere in the growth of most crop plants.

Kumar (2005) revealed that all the major processes such as photosynthesis, protein synthesis, and energy and lipid metabolism are affected by salt stress. Soil salinity, resulting from natural processes or from crop irrigation with saline water, occurs in many arid to semi-arid regions of the world (Lauchli and Epstein, 1990). In warm and dry areas salt concentration increases in the upper soil layer due to high water losses which exceed precipitation (Ebert et al., 2002). Overcoming salt stress is the main issue in these regions to ensure agricultural sustainability and crop production. Plants vary greatly in their tolerance to salts.

Wheat (Triticum aestivum L.) is a major cereal crop in the world and is a moderately salinity tolerant crop. Salinity can affect any process in the plant's life cycle. Like other crops, salinity adversely affects the growth and yield of wheat crop (Saboora and Kiarostami, 2006; Mehmet, et al., 2006). Wheat is considered to have high nutritive value in the world. The grains of wheat contain large amounts of proteins, carbohydrates, minerals and vitamins. Salt in soil and irrigation water is one of the most important factors that limit plant growth and productivity. In the present study attention has been given to investigate the effect of salinity on biochemical parameters of Triticum aestivum $L$. var. Raj-3765.

\section{Materials and Methods:-}

The experiments were conducted in the Indira Gandhi Centre for Human Ecology, Environmental and Population Studies, University of Rajasthan, during winter season. The seeds of Triticum aestivum L. var. Raj-3765 were obtained from Agriculture Research Centre, Rajasthan Agriculture University of Bikaner located in Durgapura, Jaipur, Rajasthan. Earthen pots (with a diameter of $12 \mathrm{inch}$ ) were used for conducting pot experiment for the test plant species. The seeds were surface sterilized with dilute solution hypo chloride to prevent any fungal contamination. The seeds were sown in earthen pots containing equal quantities of soil. 10 seeds were sown in the beginning in each pot and then five seedlings were allowed to grow in each pot after15 days of germination. Following 6 different salinity levels were maintained by diluting saline water (SW) with distilled water (DW) brought from study area i.e. Sambhar Town.

Level 1. SW: DW:: 00:100 (Control level)

Level 2. SW: DW:: 10:90

Level 3. SW: DW:: 25:75

Level 4. SW: DW:: 50:50

Level 5. SW: DW:: 75: 25

Level 6. SW: DW:: 100:00

The plants were investigated at 3 stages of their maturation at pre-flowering stage (after 78 days of treatment), peakflowering stage (after 94 days of treatment) and post-flowering stage (after 118 days of treatment). Plants were harvested for different biochemical parameters. Carbohydrate content was estimated by following the anthrone method, Nitrogen and protein content was estimated by microkjeldhal's method and Phosphorus content was estimated by colorimetrically by stannous chloride- ammonium molybdate method. The protein content was calculated as follows:

Percent protein $=$ percent nitrogen $\times 6.25$

\section{Results and Discussion:-}

In the present study saline water which was used for irrigation at different concentration level showed adverse effect on plant growth. The Chloride concentration of saline water was noted to be $3890 \mathrm{mg} / \mathrm{L}$ at level 6 . Plant growth decreased gradually as the salinity increased. All the biochemical parameters including carbohydrate, phosphorus, plant nitrogen and protein were adversely affected with the increasing concentration of salinity as given in tables 1 and 2.

Carbohydrate and phosphorus content was $40.32 \mathrm{mg} / \mathrm{gm}, 54.47 \mathrm{mg} / \mathrm{gm}, 55.12 \mathrm{mg} / \mathrm{gm}$ and $3.19 \mathrm{mg} / \mathrm{gm}, 3.28 \mathrm{mg} / \mathrm{gm}$, $3.308 \mathrm{mg} / \mathrm{gm}$ in the controlled condition at pre-flowering, peak-flowering and post-flowering stage and slightly increased at salinity level 2 and it was $45.35 \mathrm{mg} / \mathrm{gm}, 58.83 \mathrm{mg} / \mathrm{gm}, 60.74 \mathrm{mg} / \mathrm{gm}$ and $3.484 \mathrm{mg} / \mathrm{gm}, 3.546 \mathrm{mg} / \mathrm{gm}$, 
$3.724 \mathrm{mg} / \mathrm{gm}$. Then there was continuous decrease in carbohydrate and phosphorus content (Table 1, Figure 1 and Figure 2).

Nitrogen and protein content was 0.702 percent, 0.973 percent, 1.703 percent and 4.38 percent, 6.08 percent, 10.64 percent in the controlled condition at pre-flowering, peak-flowering and post-flowering stage respectively and it slightly increased at salinity level 2 and it was 1.112 percent, 1.462 percent, 2.078 percent and 6.95 percent, 9.13 percent, 12.98 percent. Then there was continuous decrease in nitrogen and protein content (Table 2, Figure 3 and Figure 4).

All biochemical parameters are affected by salinity including carbohydrate, phosphorus, plant nitrogen and protein. Salinity is the major environmental factor limiting plant growth and productivity. According to Tanji (1990), 20\% of cultivated land worldwide is adversely affected by high salt concentration, which inhibits plant growth and yield. Salt stress has adverse effect on carbohydrate contents. Some authors have reported carbohydrates accumulation in various plants under salinity condition (Abd El- Samad and Azooz, 2002; Parida, 2003 and Azooz, 2004). Soluble protein is generally decreased in response to salinity (Parida, 2002 and Abed-Latef, 2005).

The analysis of variance (ANOVA) revealed that sum of squares due to treatment level, harvesting stages and interaction between treatment level and harvesting stages were highly significant for all the biochemical parameters. It revealed that increase in salinity, affected all parameters (Table 3).

Table 1:- Effect of salinity on Carbohydrates and Phosphorus (mg/gm) in wheat (Triticum aestivum L.) through pot experiment.

\begin{tabular}{|c|c|c|c|c|c|c|c|}
\hline $\mathrm{L}$ & \multirow[b]{2}{*}{$\begin{array}{c}\text { Concentratio } \\
n\end{array}$} & \multicolumn{3}{|c|}{ Carbohydrate (mg/gm) } & \multicolumn{3}{|c|}{ Phosphorus (mg/gm) } \\
\hline $\begin{array}{l}E \\
V \\
E \\
1\end{array}$ & & $\begin{array}{c}\text { Pre- } \\
\text { Flowering } \\
\text { Stage }\end{array}$ & $\begin{array}{c}\text { Peak- } \\
\text { Flowering } \\
\text { Stage }\end{array}$ & $\begin{array}{c}\text { Post- } \\
\text { Flowering } \\
\text { Stage }\end{array}$ & $\begin{array}{c}\text { Pre- } \\
\text { Flowering } \\
\text { Stage }\end{array}$ & $\begin{array}{l}\text { Peak- } \\
\text { Flowering } \\
\text { Stage }\end{array}$ & $\begin{array}{c}\text { Post- } \\
\text { Flowering } \\
\text { Stage }\end{array}$ \\
\hline 1 & 100:00 & $40.32 \pm 0.2141$ & $\begin{array}{l}54.47 \pm 0.095 \\
6\end{array}$ & $\begin{array}{l}55.12 \pm 0.165 \\
9\end{array}$ & $3.19 \pm 0.0514$ & $3.28 \pm 0.1077$ & $\begin{array}{l}3.308 \pm 0.101 \\
5\end{array}$ \\
\hline 2 & $90: 10$ & $45.35 \pm 0.2804$ & $\begin{array}{l}58.83 \pm 0.071 \\
7\end{array}$ & $\begin{array}{l}60.74 \pm 0.087 \\
4\end{array}$ & $\begin{array}{l}3.484 \pm 0.093 \\
4\end{array}$ & $\begin{array}{l}3.546 \pm 0.082 \\
6\end{array}$ & $\begin{array}{l}3.724 \pm 0.071 \\
6\end{array}$ \\
\hline 3 & $75: 25$ & $43.27 \pm 0.0620$ & $\begin{array}{l}56.38 \pm 0.071 \\
4\end{array}$ & $\begin{array}{l}57.96 \pm 0.169 \\
5\end{array}$ & $3.26 \pm 0.1124$ & $\begin{array}{l}3.424 \pm 0.127 \\
0\end{array}$ & $3.67 \pm 0.0781$ \\
\hline 4 & $50: 50$ & $42.11 \pm 0.1568$ & $\begin{array}{l}55.44 \pm 0.168 \\
9\end{array}$ & $\begin{array}{l}56.34 \pm 0.075 \\
4\end{array}$ & $\begin{array}{l}3.246 \pm 0.115 \\
4\end{array}$ & $\begin{array}{l}3.402 \pm 0.082 \\
8\end{array}$ & $3.56 \pm 0.0946$ \\
\hline 5 & $25: 75$ & $39.7 \pm 0.1118$ & $\begin{array}{l}53.04 \pm 0.128 \\
6\end{array}$ & $54.5 \pm 0.0886$ & $3.15 \pm 0.0696$ & $\begin{array}{l}3.228 \pm 0.090 \\
9\end{array}$ & $\begin{array}{l}3.254 \pm 0.119 \\
4\end{array}$ \\
\hline 6 & $00: 100$ & $35.54 \pm 0.0827$ & $\begin{array}{l}50.22 \pm 0.081 \\
5\end{array}$ & $\begin{array}{l}51.12 \pm 0.092 \\
7\end{array}$ & $\begin{array}{l}3.068 \pm 0.055 \\
4\end{array}$ & $3.16 \pm 0.1041$ & $3.21 \pm 0.1077$ \\
\hline
\end{tabular}

Table 2:- Effect of salinity on Nitrogen and Protein (\%) in wheat (Triticum aestivum L.) through pot experiment.

\begin{tabular}{|c|c|c|c|c|c|c|c|}
\hline \multirow{2}{*}{$\begin{array}{l}\mathrm{L} \\
\mathrm{E} \\
\mathrm{V} \\
\mathrm{E} \\
1\end{array}$} & \multirow{2}{*}{$\begin{array}{c}\text { Concentration } \\
\text { DW:SW }\end{array}$} & \multicolumn{3}{|c|}{ Nitrogen $(\%)$} & \multicolumn{3}{|c|}{ Protein $(\%)$} \\
\hline & & $\begin{array}{l}\text { Pre- } \\
\text { Flowering } \\
\text { Stage }\end{array}$ & $\begin{array}{l}\text { Peak- } \\
\text { Flowering } \\
\text { Stage }\end{array}$ & $\begin{array}{l}\text { Post- } \\
\text { Flowering } \\
\text { Stage }\end{array}$ & $\begin{array}{l}\text { Pre- } \\
\text { Flowering } \\
\text { Stage }\end{array}$ & $\begin{array}{l}\text { Peak- } \\
\text { Flowering } \\
\text { Stage }\end{array}$ & $\begin{array}{l}\text { Post- } \\
\text { Flowering } \\
\text { Stage }\end{array}$ \\
\hline 1 & 100:00 & $0.702 \pm 0.0785$ & $0.973 \pm 0.1231$ & $1.703 \pm 0.0673$ & $4.38 \pm 0.2514$ & $6.08 \pm 0.7699$ & $10.64 \pm 0.4207$ \\
\hline 2 & $90: 10$ & $1.112 \pm 0.0794$ & $1.462 \pm 0.1052$ & $2.078 \pm 0.0332$ & $6.95 \pm 0.4968$ & $9.13 \pm 0.3681$ & $12.98 \pm 0.2077$ \\
\hline 3 & $75: 25$ & $0.923 \pm 0.1143$ & $1.156 \pm 0.0475$ & $2.011 \pm 0.0844$ & $5.76 \pm 0.2966$ & $7.22 \pm 0.2972$ & $12.56 \pm 0.5278$ \\
\hline 4 & $50: 50$ & $0.814 \pm 0.0879$ & $1.045 \pm 0.0787$ & $1.884 \pm 0.0690$ & $5.08 \pm 0.2382$ & $6.53 \pm 0.4923$ & $11.77 \pm 0.4315$ \\
\hline 5 & $25: 75$ & $0.612 \pm 0.0736$ & $0.714 \pm 0.0852$ & $1.265 \pm 0.0772$ & $3.82 \pm 0.4601$ & $4.46 \pm 0.5329$ & $7.90 \pm 0.4831$ \\
\hline 6 & $00: 100$ & $0.487 \pm 0.0428$ & $0.596 \pm 0.0453$ & $0.945 \pm 0.0396$ & $3.04 \pm 0.2675$ & $3.72 \pm 0.2833$ & $5.90 \pm 0.2479$ \\
\hline
\end{tabular}




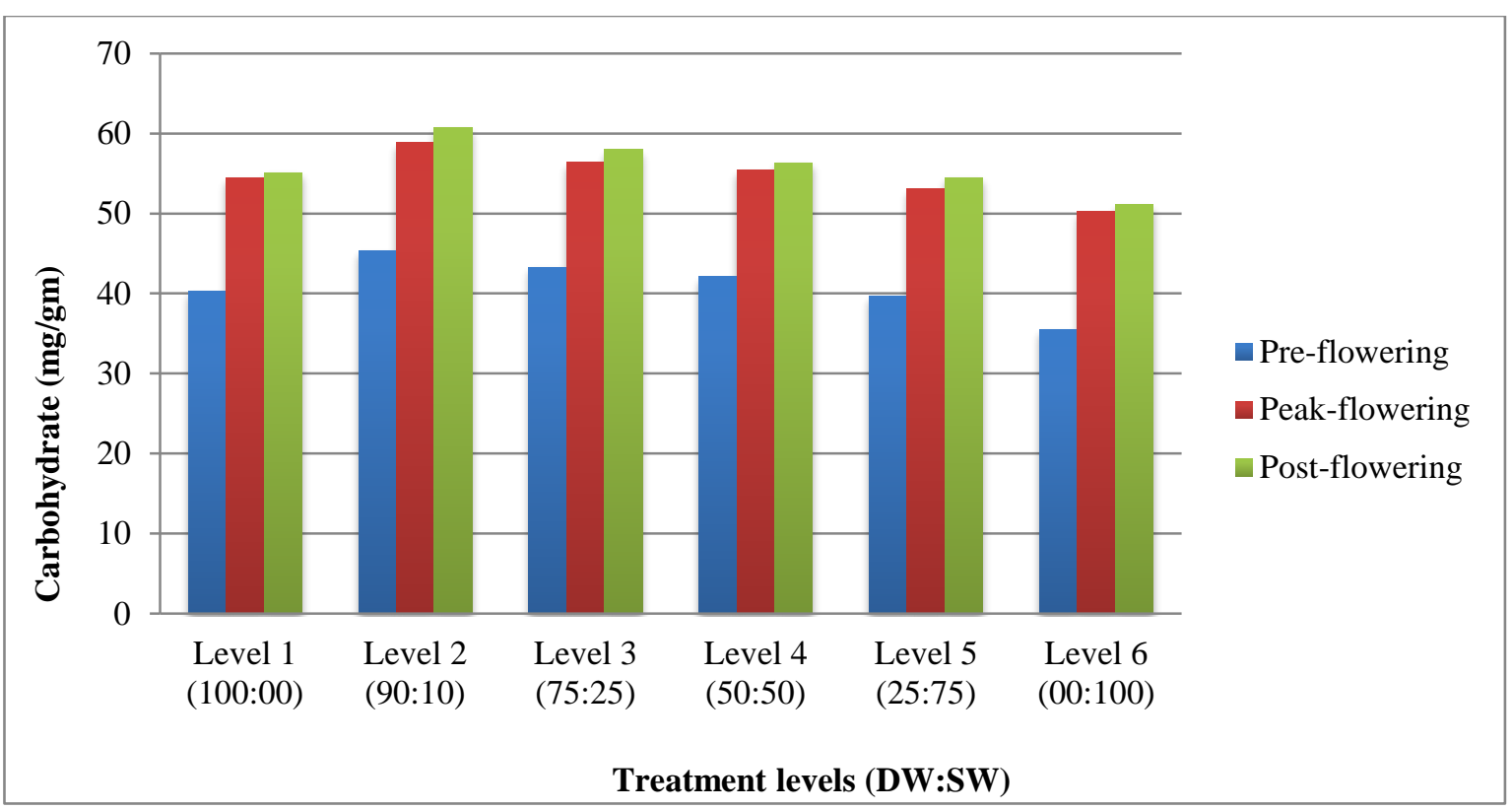

Figure1:- Effect of different salinity levels on Carbohydrate (mg/gm) of Triticum aestivum L. var. Raj-3765 (Wheat) through pot experiment

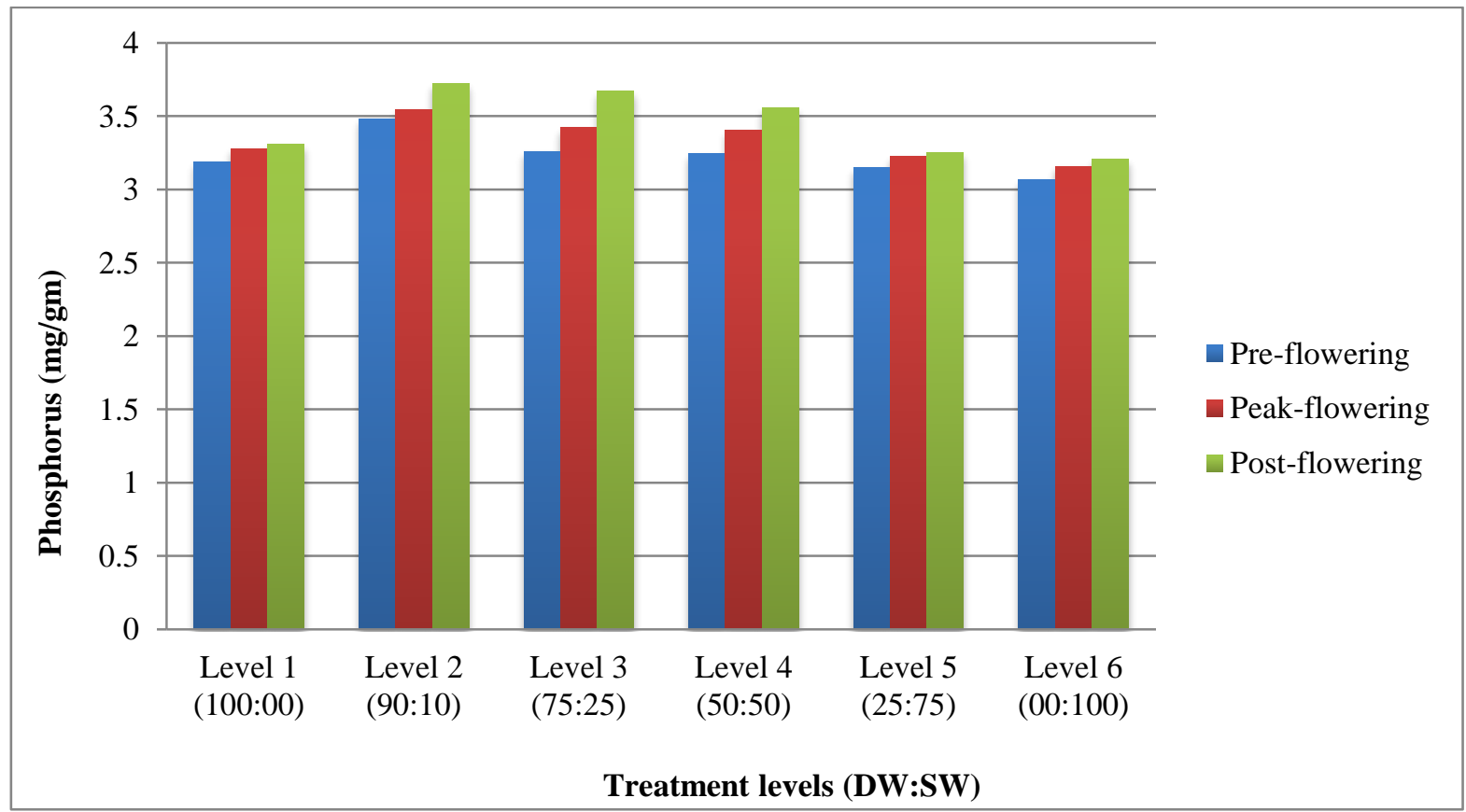

Figure 2:- Effect of different salinity levels on Phosphorus (mg/gm) of Triticum aestivum L. var. Raj-3765 (Wheat) through pot experiment 


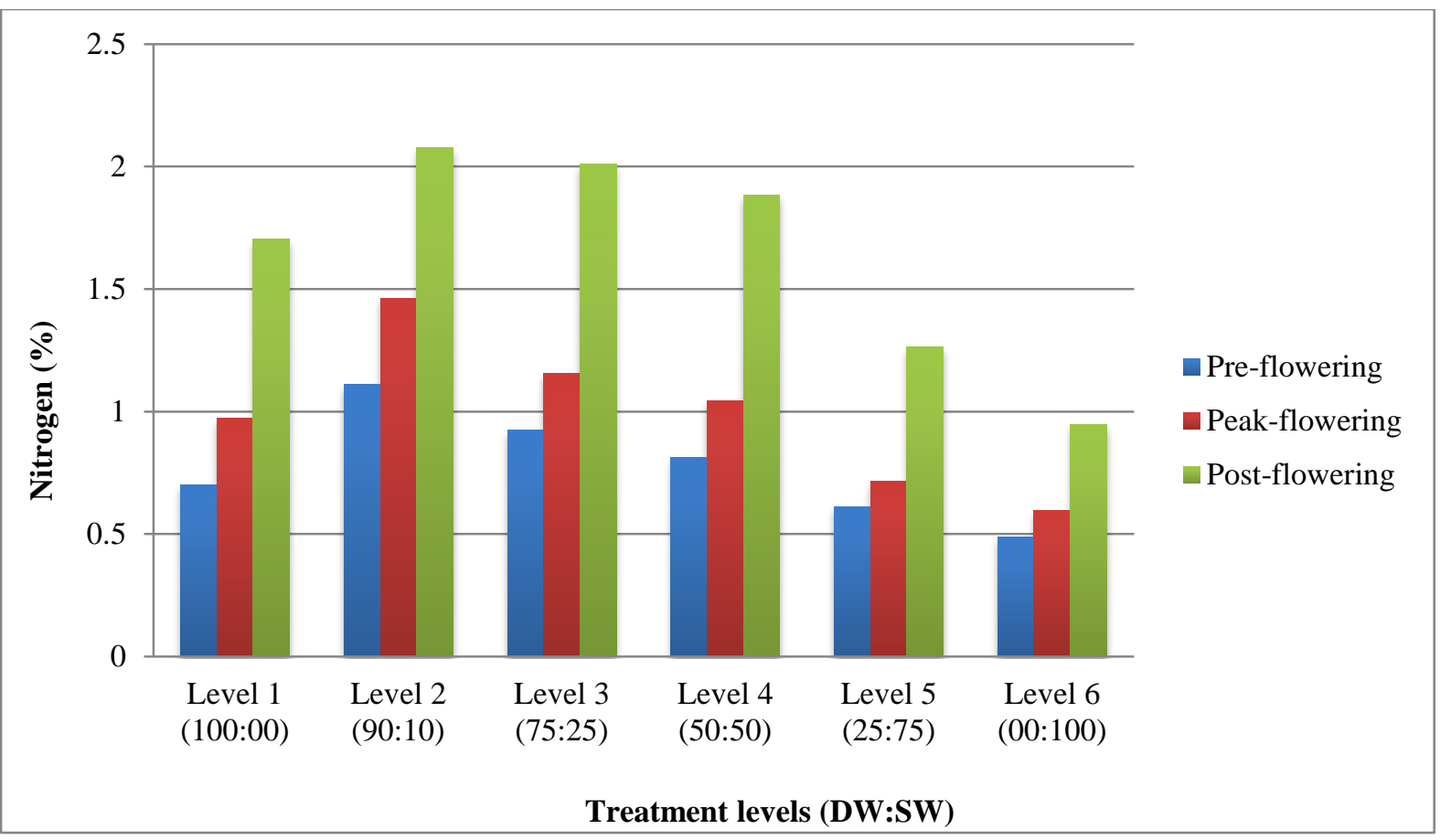

Figure 3:- Effect of different salinity levels on Nitrogen (\%) of Triticum aestivum L. var. Raj-3765 (Wheat) through pot experiment.

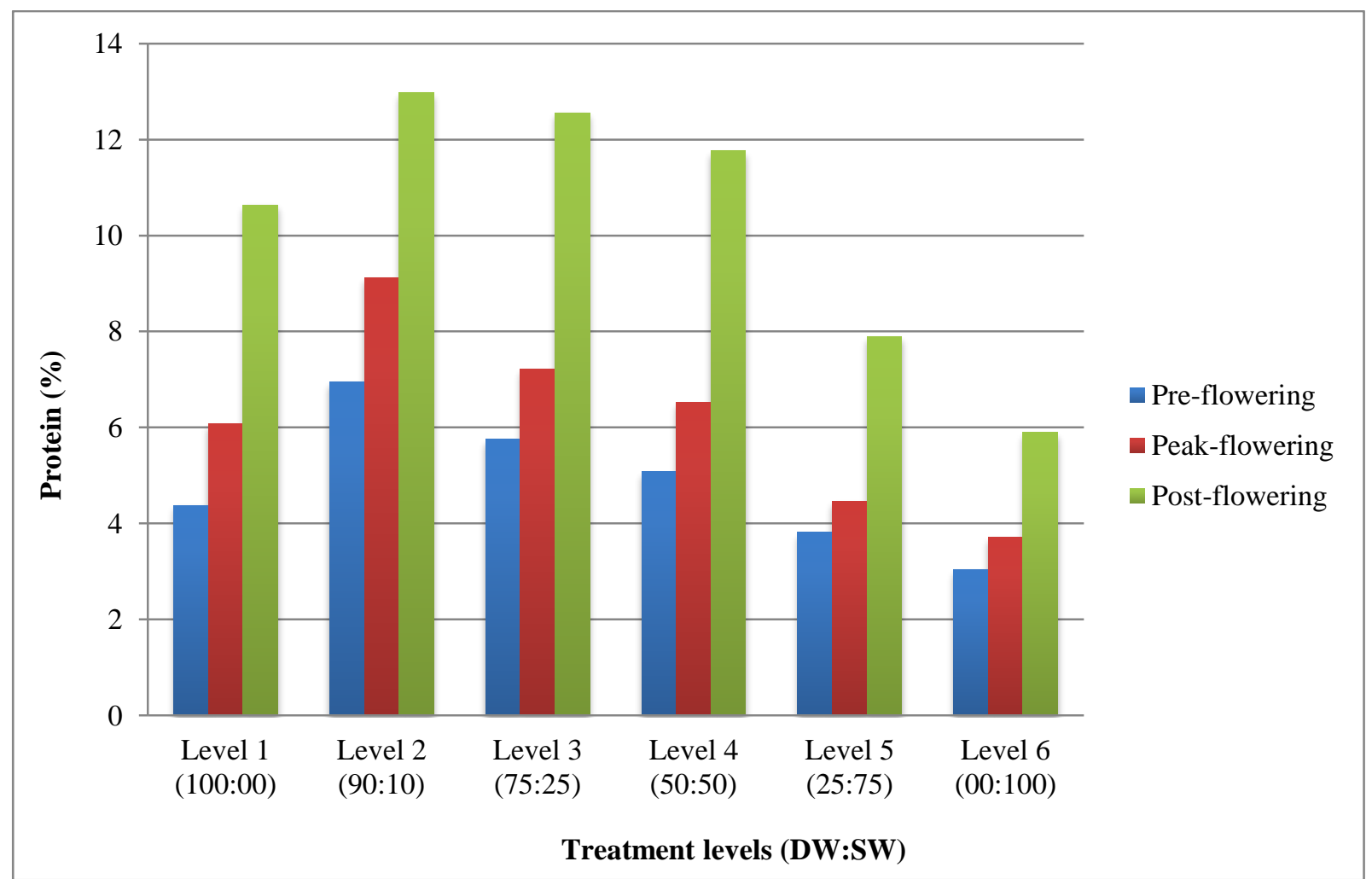

Figure 4:- Effect of different salinity levels on Protein (\%) of Triticum aestivum L. var. Raj-3765 (Wheat) through pot experiment 
Table 3:- Mean sum of squares due to effect of different levels of salinity on different parameters of wheat (Triticum aestivum L. var. Raj-3765).

\begin{tabular}{|l|l|l|l|l|l|}
\hline Source & DF & Carbohydrate & Nitrogen & Protein & Phosphorus \\
\hline Stage & 2 & 2055.832 & 6.197 & 242.079 & 0.368 \\
& & $(1.62 \mathrm{E}-126 * *)$ & $\left(1.66 \mathrm{E}-53^{* *}\right)$ & $(3.25 \mathrm{E}-58 * *)$ & $(1.43 \mathrm{E}-12 * *)$ \\
\hline Level & 5 & 152.403 & 1.566 & 61.163 & 0.411 \\
& & $\left(5.94 \mathrm{E}-98^{* *}\right)$ & $\left(1.95 \mathrm{E}-44^{* *}\right)$ & $(4.71 \mathrm{E}-49 * *)$ & $(5.54 \mathrm{E}-21 * *)$ \\
\hline Int.Stg $\mathbf{x}$ & 10 & 0.705 & 0.094 & 3.659 & 0.021 \\
Level & & $(5.98 \mathrm{E}-25 * *)$ & $(2.82 \mathrm{E}-14 * *)$ & $(1.37 \mathrm{E}-17 * *)$ & $(1.84 \mathrm{E}-02 * *)$ \\
\hline Error & 72 & 0.018 & 0.006 & 0.175 & 0.009 \\
\hline
\end{tabular}

Data in parenthesis indicate $\mathrm{P}$ values.

**Significant at $1 \%$.

\section{Conclusion:-}

The results of this study showed that salinity stress had significant effect on carbohydrate, phosphorus, nitrogen and protein content. All the biochemical parameters were highest at level 2 (SW: DW:: 10:90). Therefore, The best growth of this crop plant was observed at level 2 i.e. SW: DW:: 10:90. Beyond this level of salinity adverse effects were found. Our work showed that use of saline water in irrigation increased the concentration of salts. There is a requirement of such studies and research work in agricultural fields. Also the nutrient value of the plant seeds decreases due to salinity. Plants vary greatly in their tolerance to salts. Production of salt tolerant plants is one of the ways to utilize the waste saline water and lands.

\section{Acknowledgements:-}

The authors are grateful to the Dean, Faculty of Science, University of Rajasthan and Director, Indira Gandhi Centre for Human Ecology, Environment and Population Studies, University of Rajasthan for providing necessary facilities and to UGC for the award of Rajiv Gandhi National Research Fellowship to one of the authors.

\section{References:-}

1. Abdel-Latef, A.A. (2005): Salt tolerance of some wheat cultivars. Ph.D.Thesis, South valley Univ. Qena, Egypt., 1-159.

2. Abd el Samad, H.M. (1993): Counteraction of $\mathrm{NaCl}$ and $\mathrm{CaCl} 2$ and $\mathrm{KCl}$ on pigment, saccharide and mineral contents in wheat. Biol. Plant., 35: 555-560.

3. Azooz, M.M.,Shaddad, M.A. and Abdel-Latef, A.A. (2004): The accumulation and compartmentation of proline in relation to salt tolerance of three sorghum cultivars. Ind. J. Plant Physiol., 9:1-8.

4. Ebert, G., Eberle, J., Ali-Dinar, H. andLüdders, P. (2002): Ameliorating effects of $\mathrm{Ca}(\mathrm{NO} 3) 2$ on growth, mineral uptake and photosynthesis of $\mathrm{NaCl}$-stressed guava seedlings (Psidiumguajava L.). Scien.Hortic., 93:125-135.

5. Flowers, T.J., Garcia, A., Koyama, M. and Yeo, A.R., (1997): Breeding for salt tolerance in crop plants- the role of molecular biology. Acta. Physiol. Plantar., 19: 427-433.

6. Kumar, P. and Das, A. (2005): Salt tolerance and salinity effects on plants. Ecotoxicology and Environmental Safety., 60: 324-349.

7. Lauchli, A. and Epstein, E. (1990): Plant responses to saline and sodic conditions. In: Tanji KK (ed), Agricultural Salinity Assessment and Management ASCE, New York., 113-137.

8. Mala, K. and Khan, T.I. (2014): Study of salinity in selected areas of sambhar town, GJBB., 3(3): 334-335.

9. Mehmet, A., Kaya, M.D. and Kaya, G. (2006): Effects of $\mathrm{NaCl}$ on the germination, seedling growth and water uptake of triticale. Turkish Journal of Agriculture and Forestry., 30: 39-47.

10. Munns, R., James, R. A. and Luchli, A. (2006):Approaches to increasing the salt tolerance of wheat and other cereals, J. Exp. Bot., 57: 1025-1030.

11. Saboora, A. and Kiarostami, K. (2006): Salinity tolerance of wheat genotype at germination and early seedling growth. Pakistan Journal of Biological Sciences., 9: 2009-2021.

12. Tanji, K.K. (1990): Nature and extent of agricultural salinity. Agricultural Salinity Assessment and Management,ASCE, New York.,1-13. 